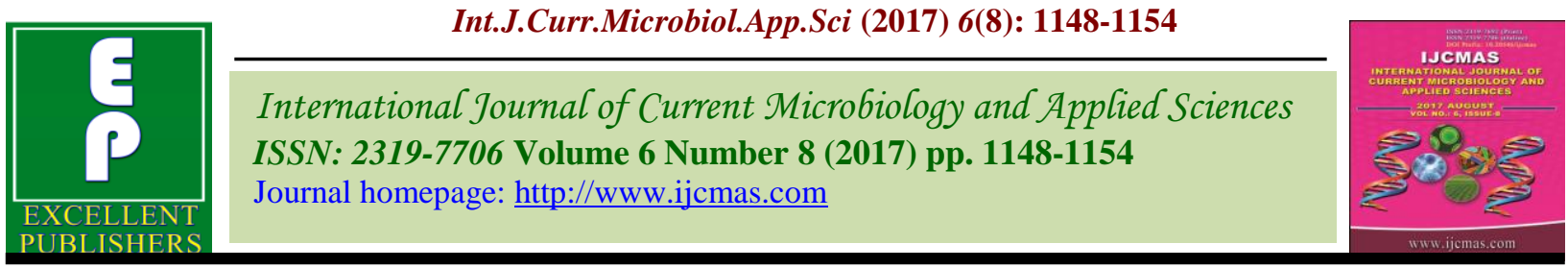

Original Research Article https://doi.org/10.20546/ijcmas.2017.608.142

\title{
Reactions of Genotypes of Barley with Aphid (Rhopalosiphum maidis) Population
}

\author{
Pawan Kumar Choudhary*, Suresh Jakhar and K.C. Kumawat \\ Department of Entomology, S.K.N Agriculture University, Jobner-303328, Rajasthan, India \\ *Corresponding author
}

A B S T R A C T

Fifteen genotypes of barley were screened for their comparative resistance to aphid, R. maidis in Rabi 2014-15 at the Agronomy farm of SKN College of

Keywords

Aphid, Barley,

Genotypes,

Susceptibility.

Article Info

Accepted:

17 June 2017

Available Online:

10 August 2017

Agriculture, Sri Karan Narendra Agriculture University, Jobner (Rajasthan). The mean aphid population of all the observations ranged from 19.86 to 49.56 aphids per tiller. The minimum mean aphid population was found on genotype, RD-2035 (19.86 aphids/ tiller) followed by RD-2552 (22.41 aphids/ tiller), RD-2849 (24.74 aphids/ tiller) and RD-2794 (25.84 aphid/ tiller), these were differed nonsignificantly in their degree of infestation each other and differed significantly over rest of the genotypes. The maximum mean aphid population was found on genotype, RD-2624 (49.56 aphids/ tiller) followed by RD-2052 (48.97 aphids/ tiller), these were statistically at par with each other in their degree of infestation. The genotypes viz., RD-2035, RD-2552 and RD-2794 were found as least susceptible; RD-2503, RD-2508, RD-2793, PL-426, RD-2592, RD-2660, RD2668, RD-2715 and RD-2786 and RD-2849 as moderately susceptible; whereas, RD-2052 and RD-2624 as highly susceptible.

\section{Introduction}

Barley, Hordeum vulgare Linn. (Family: Gramineae) is an important cereal crop of Rabi season grown in India. The chapattis made up of barley flour are very palatable and can be easily digested even by the persons suffering from stomach ailments. Besides an ideal feed and fodder for livestock, the crop has acquired the status of an industrial crop in malting and brewing. This crop could perform better under moisture stress and saline conditions than other cereal crops. The grains of barley contain 12.5 per cent moisture, 11.5 per cent albuminoids, 74.0 per cent carbohydrate, 1.3 per cent fat, 3.9 per cent crude fibre and 1.5 per cent ash. In Rajasthan, it is cultivated in about 307,936 ha area with an annual production to the tune of 957,896 tonnes (Anonymous, 2013).

The crop is infested by a number of insect pests, viz., armyworm, Mythimna separata (Haworth); ghujhia weevil, Tanymecus indicus (Faust); termite, Odontotermes obesus (Ramb.); cutworms, Agrotis spp.; shoot fly, Atherigona naquii (Styskal); pink borer, Sesamia inferens (Walker); jassids, Amrasca basalis (Baly); barley aphid, Rhopalosiphum maidis (Fitch) and R. padi (Linn.) (Singh, 
1983). Among these insect pests, the aphid, $R$. maidis is most serious and regular insect pest of this crop (Sharma, 1990; Kumawat and Jheeba, 1999). Both nymphs and adults cause damage by sucking the cell sap from the leaves, stems and earheads. Due to rapid multiplication of the aphid, usually the entire shoot is covered and with the result of continuous desaping by such a large population, yellowing, curling and subsequent drying of leaves takes place which ultimately lead to reduction in size of earheads (Bhatia and Singh, 1977). The aphid also acts as a vector of barley yellow dwarf virus.

The growing of resistant varieties have utmost importance in the crop protection because it does not incur extra cost to minimize the damage and used as a prophylactic measure against insect pests. In past, some varieties/ germplasms of barley were screened against insect pests by many workers (Yadav and Jain, 2000; Singh et al., 2006), however, these have been replaced by new high yielding varieties on which such work is lacking.

\section{Materials and Methods}

The experiment was laid out in simple randomized block design (RBD) with 15 treatments (genotypes), each replicated thrice. The plot size was $3.0 \times 2.25 \mathrm{~m}^{2}$ with row to row distance of $25 \mathrm{~cm}$, respectively. The barley genotypes were sown on $15^{\text {th }}$ November, 2014. The names of different genotypes and their source of supply are given in table 1 .

\section{Observations}

The genotypes were allowed to have natural infestation of aphid, $R$. maidis. The observations on the population of aphid were recorded on five randomly selected and tagged plants (5 tillers/ plant) from each plot at weekly interval starting from its appearance till harvesting of the crop. Different morphological characters, viz., plant height, number of tillers/ metre row, days to earing and days to maturity were recorded.

\section{Interpretation of data}

The data obtained on aphid population from the experimental field were transformed into $\sqrt{\mathrm{X}+0.5}$ (Gomez and Gomez, 1976) and subjected to analysis of variance. The peak population of aphid on barley genotypes recorded during the crop season was categorized on the basis of formula:

$\overline{\mathrm{X}} \pm \sigma$

Where,

$\overline{\mathrm{X}}=$ Mean of peak population

$\sigma=$ Standard deviation

\section{Results and Discussion}

The population on different genotypes of barley appeared in the first week of January, 2015. The mean aphid population increased gradually and reached to peak in the fifth observation $\left(01^{\text {th }}\right.$ February, 2015). The aphid population increased considerably which was found in the range of 47.23 to 110.59 aphids/ tiller. The least aphid infestation was observed on genotypes RD-2035 (47.23 aphids/ tiller) and RD-2794 (52.15 aphids/ tiller), these were statistically comparable to each other in their degree of resistance. The maximum aphid population was recorded on RD-2624 (110.59 aphids/ tiller) and RD-2052 (106.60 aphids/ tiller), these were stood at par with each other. The RD-2503 (87.58 aphid/ tiller) differed non-significantly with RD2660 (79.50 aphids/ tiller). The other genotypes were grouped in middle order of infestation. In the last observation $\left(22^{\text {nd }}\right.$ February, 2015), the aphid population was drastically reduced, being minimum on RD- 
2035 (7.63 aphids/ tiller) and maximum on RD-2052 (19.70 aphids/ tiller).

The mean aphid population of all the observations ranged from 19.86 to 49.56 aphids per tiller. The minimum mean aphid population was found on genotype, RD-2035 (19.86 aphids/ tiller) followed by RD-2552 (22.41 aphids/ tiller), RD-2849 (24.74 aphids/ tiller) and RD-2794 (25.84 aphid/ tiller), these were differed non-significantly in their degree of infestation each other and differed significantly over rest of the genotypes. The maximum mean aphid population was found on genotype, RD-2624 (49.56 aphids/ tiller) followed by RD-2052 (48.97 aphids/ tiller), these were statistically at par with each other in their degree of infestation. The rest of the genotypes were ranked in middle order of infestation. The descending order of infestation of all the genotypes based on mean aphid population was found to be RD-2624, RD-2052, RD-2503, RD-2660, PL-426, RD2508, RD-2592, RD-2715, RD-2793, RD2668, RD-2786, RD-2794, RD-2849, RD2552, RD-2035 (Table 2).

For the sake of convenience in concluding the result, the peak aphid population on barley genotypes was categorized on the basis of formula $\bar{X} \pm \sigma$. The genotypes having aphid population below 56.12, 56.12 to 91.08 and above 91.08 per tiller were categorized as least susceptible, moderately susceptible and highly susceptible, respectively. Taking the above criterion into consideration, the genotypes viz., RD-2035, RD-2552 and RD2794 were considered as least susceptible; RD-2503, RD-2508, RD-2793, PL-426, RD-
2592, RD-2660, RD-2668, RD-2715 and RD2786 and RD-2849 as moderately susceptible; and RD-2052 and RD-2624 as highly susceptible. The order of variability in barley genotypes keeping in consideration the peak aphid population and the mean aphid population of all the observations recorded during the crop season was more or less same (Table 3).

The morphological characters of different barley genotypes, viz., plant height, tillers per metre row, days to earing and maturity were recorded to find out their relationship with aphid incidence and it could be concluded that these did not affect the aphid population significantly (Table 4).

In the present investigation 15 genotypes of barley viz., RD-2035, RD-2052, RD-2503, RD-2552，RD-2508，RD-2552， RD-2592, RD-2624， RD-2663， RD-2668， RD-2715, RD-2786, RD-2793, RD-2794, RD-2849, PL426 were screened for their comparative resistance to aphid, $R$. maidis. The results revealed that none of the genotypes was found completely free from aphid infestation. The present findings are in conformity with that of Chhilar et al., (1985) and Singh et al., (2006) who reported that out of 30 barley cultivars screened against $R$. maidis, none of them was found resistant to the pest.

The data revealed that significant difference existed among the genotypes of barley with regards to aphid population. During peak, maximum aphid population was observed on genotype, RD-2624 (110.59 aphids /tiller) and minimum on RD-2035 (47.23 aphids/ tiller).

Table.1 Different barley genotypes studied for reactions with aphid, Rhopalosiphum maidis (Fitch) and their source of supply

\begin{tabular}{ll}
\hline Name of genotypes & Source of supply \\
\hline RD-2035, RD-2052, RD-2503, RD-2508, RD-2552, & Rajasthan Agricultural Research Institute, \\
RD-2592, RD-2624, RD-2660, RD-2668, RD-2715, & Durgapura, Jaipur \\
RD-2786, RD-2793, RD-2794, RD-2849 and PL-426 & \\
\hline
\end{tabular}


Table.2 Reactions of genotypes of barley with aphid, Rhopalosiphum maidis (Fitch) population

\begin{tabular}{|c|c|c|c|c|c|c|c|c|c|}
\hline \multirow[t]{2}{*}{ Genotypes } & \multicolumn{8}{|c|}{ Weekly mean aphid, $R$. maidis population/ tiller* } & \multirow{2}{*}{ Mean } \\
\hline & 04.01 .2015 & 11.01 .2015 & 18.01 .2015 & 25.01 .2015 & $01.02 .2015 * *$ & 08.02 .2015 & 15.02 .2015 & 22.02 .2015 & \\
\hline \multirow[t]{2}{*}{ 1. RD-2035 } & 4.20 & 6.44 & 19.33 & 33.02 & 47.23 & 28.40 & 12.63 & 7.63 & 19.86 \\
\hline & $(2.17)$ & $(2.63)$ & $(4.45)$ & $(5.79)$ & $(6.91)$ & $(5.38)$ & $(3.62)$ & $(2.85)$ & $(4.51)$ \\
\hline \multirow[t]{2}{*}{ 2. RD-2052 } & 18.35 & 27.54 & 52.54 & 78.28 & 106.60 & 67.08 & 21.66 & 19.70 & 48.97 \\
\hline & $(4.34)$ & $(5.30)$ & $(7.28)$ & $(8.88)$ & $(10.35)$ & $(8.22)$ & $(4.71)$ & $(4.49)$ & (7.03) \\
\hline \multirow[t]{2}{*}{ 3. RD-2503 } & 9.26 & 20.15 & 44.60 & 60.80 & 87.58 & 61.26 & 15.66 & 13.87 & 39.15 \\
\hline & (3.12) & $(4.54)$ & $(6.72)$ & $(7.83)$ & (9.39) & $(7.86)$ & $(4.02)$ & $(3.79)$ & (6.30) \\
\hline \multirow[t]{2}{*}{ 4. RD-2508 } & 6.12 & 19.09 & 35.02 & 56.82 & 77.01 & 47.08 & 14.60 & 12.60 & 33.54 \\
\hline & $(2.57)$ & $(4.43)$ & (5.96) & $(7.57)$ & (8.80) & (6.90) & (3.89) & $(3.62)$ & $(5.83)$ \\
\hline \multirow[t]{2}{*}{ 5. RD-2552 } & 5.18 & 12.62 & 24.06 & 35.73 & 54.52 & 29.45 & 9.87 & 7.87 & 22.41 \\
\hline & $(2.38)$ & $(3.62)$ & $(4.96)$ & $(6.02)$ & $(7.42)$ & $(5.47)$ & (3.22) & $(2.89)$ & (4.79) \\
\hline \multirow[t]{2}{*}{ 6. RD-2592 } & 6.70 & 16.44 & 34.00 & 51.62 & 70.40 & 47.08 & 13.09 & 11.09 & 31.30 \\
\hline & $(2.68)$ & (4.12) & (5.87) & $(7.22)$ & $(8.42)$ & (6.90) & $(3.69)$ & $(3.40)$ & $(5.64)$ \\
\hline \multirow[t]{2}{*}{ 7. RD-2624 } & 16.17 & 29.25 & 54.44 & 81.70 & 110.59 & 68.74 & 18.29 & 17.29 & 49.56 \\
\hline & $(4.08)$ & $(5.45)$ & (7.41) & $(9.07)$ & $(10.54)$ & $(8.32)$ & (4.33) & $(4.22)$ & (7.08) \\
\hline \multirow[t]{2}{*}{ 8. RD-2660 } & 6.72 & 19.23 & 40.03 & 57.22 & 79.50 & 55.04 & 13.90 & 11.90 & 35.44 \\
\hline & (2.69) & $(4.44)$ & (6.37) & $(7.60)$ & (8.94) & $(7.45)$ & $(3.79)$ & $(3.52)$ & $(6.00)$ \\
\hline \multirow[t]{2}{*}{ 9. RD-2668 } & 8.60 & 11.51 & 33.47 & 47.90 & 67.86 & 39.44 & 11.75 & 9.75 & 28.79 \\
\hline & (3.02) & $(3.47)$ & $(5.83)$ & $(6.96)$ & (8.27) & $(6.32)$ & $(3.50)$ & $(3.20)$ & $(5.41)$ \\
\hline \multirow[t]{2}{*}{ 10. RD-2715 } & 7.16 & 12.10 & 28.15 & 45.80 & 79.20 & 40.60 & 13.30 & 12.30 & 29.83 \\
\hline & $(2.77)$ & $(3.55)$ & $(5.35)$ & $(6.80)$ & (8.93) & $(6.41)$ & $(3.71)$ & $(3.58)$ & $(5.51)$ \\
\hline \multirow[t]{2}{*}{ 11. RD-2786 } & 5.19 & 15.50 & 25.15 & 52.20 & 66.40 & 31.15 & 10.17 & 8.17 & 26.74 \\
\hline & (2.39) & $(4.00)$ & (5.06) & $(7.26)$ & (8.18) & $(5.63)$ & $(3.27)$ & (2.94) & $(5.22)$ \\
\hline \multirow[t]{2}{*}{ 12. RD-2793 } & 8.50 & 11.30 & 29.40 & 47.48 & 72.20 & 34.68 & 15.50 & 13.50 & 29.07 \\
\hline & $(3.00)$ & $(3.44)$ & $(5.47)$ & (6.93) & (8.53) & $(5.93)$ & $(4.00)$ & $(3.74)$ & $(5.44)$ \\
\hline \multirow[t]{2}{*}{ 13. RD-2794 } & 6.20 & 13.17 & 32.75 & 43.40 & 52.15 & 28.56 & 16.25 & 14.25 & 25.84 \\
\hline & (2.59) & $(3.70)$ & $(5.77)$ & (6.63) & (7.26) & (5.39) & $(4.09)$ & (3.84) & (5.13) \\
\hline \multirow[t]{2}{*}{ 14. RD-2849 } & 9.40 & 16.15 & 21.18 & 32.47 & 58.20 & 39.18 & 11.15 & 10.15 & 24.74 \\
\hline & $(3.15)$ & (4.08) & (4.66) & $(5.74)$ & (7.66) & $(6.30)$ & $(3.41)$ & $(3.26)$ & $(5.02)$ \\
\hline \multirow[t]{2}{*}{ 15. PL-426 } & 11.50 & 18.20 & 35.50 & 56.15 & 74.50 & 52.20 & 12.16 & 9.06 & 33.66 \\
\hline & $(3.46)$ & $(4.32)$ & $(6.00)$ & $(7.53)$ & $(8.66)$ & $(7.26)$ & $(3.56)$ & $(3.09)$ & $(5.84)$ \\
\hline S.Em \pm & 0.10 & 0.13 & 0.15 & 0.17 & 0.18 & 0.15 & 0.12 & 0.09 & 0.23 \\
\hline $\mathrm{CD}(\mathrm{p}=0.05)$ & 0.30 & 0.39 & 0.42 & 0.49 & 0.52 & 0.44 & 0.35 & 0.25 & 0.67 \\
\hline
\end{tabular}

Figures in the parentheses are $\sqrt{ } \mathrm{X}+0.5$ values. * Mean of three replications $* *$ Peak aphid population 
Table.3 Categories of susceptibility of different barley genotypes to aphid, Rhopalosiphum maidis Fitch

\begin{tabular}{clll}
\hline S. No. & $\begin{array}{l}\text { Aphid } \\
\text { population/ tiller }\end{array}$ & Categories of susceptibility & Varieties \\
\hline 1. & $<56.12$ & Least susceptible & RD-2035, RD-2552, RD-2794 \\
2. & $56.12-91.08$ & Moderately susceptible & RD-2503, RD-2508, RD-2793, PL-426, RD-2592, RD-2660, \\
& & & RD-2668, RD-2715, RD-2786, RD-2849 \\
3. & $>91.08$ & Highly susceptible & RD-2052, RD-2624 \\
\hline
\end{tabular}

Table.4 Morphological characters of barley genotypes and their correlation with aphid, Rhophalosiphum maidis (Fitch) population

\begin{tabular}{|c|c|c|c|c|c|}
\hline \multirow[t]{2}{*}{ Genotypes } & \multicolumn{5}{|c|}{ Morphological characters } \\
\hline & $\begin{array}{l}\text { Peak aphid population } \\
\text { per tiller }\end{array}$ & Plant height (cm) & $\begin{array}{l}\text { Tillers per meter } \\
\text { row }\end{array}$ & Days to earing & $\begin{array}{c}\text { Days to } \\
\text { maturity }\end{array}$ \\
\hline 1. RD-2035 & 47.23 & 95 & 162 & 79 & 125 \\
\hline 2. RD-2052 & 106.60 & 86 & 140 & 91 & 126 \\
\hline 3. RD-2503 & 87.58 & 94 & 134 & 90 & 123 \\
\hline 4. $\mathrm{RD}-2508$ & 77.01 & 80 & 145 & 89 & 117 \\
\hline 5. RD-2552 & 54.52 & 85 & 137 & 84 & 128 \\
\hline 6. RD-2592 & 70.40 & 84 & 150 & 85 & 122 \\
\hline 7. RD-2624 & 110.59 & 75 & 112 & 86 & 119 \\
\hline 8. RD-2660 & 79.50 & 84 & 104 & 84 & 122 \\
\hline 9. RD-2668 & 67.86 & 79 & 96 & 86 & 124 \\
\hline 10. RD-2715 & 79.20 & 82 & 135 & 89 & 120 \\
\hline 11. RD-2786 & 66.40 & 74 & 120 & 82 & 118 \\
\hline 12. RD-2793 & 72.20 & 86 & 115 & 88 & 125 \\
\hline 13. RD-2794 & 52.15 & 70 & 139 & 90 & 115 \\
\hline 14. RD-2849 & 58.20 & 78 & 142 & 87 & 123 \\
\hline 15. PL-426 & 74.50 & 80 & 125 & 83 & 114 \\
\hline $\begin{array}{l}\text { Correlation coefficient with peak } \\
\text { aphid population (r) }\end{array}$ & - & 0.150 & -0.326 & 0.445 & -0.044 \\
\hline
\end{tabular}


The genotypes screened in the present investigation were not screened by any other workers in the past except a few. The genotype RD-2035 was least susceptible, RD2503, RD-2508 was moderately susceptible and RD-2052 was highly susceptible to aphid as reported by Kumawat and Jheeba (1999), supports the present findings. Singh and Jat (2011) found RD-2035 and RD-2552 as least susceptible varieties. Likewise, Sharma (2003) reported that genotype RD-2035 was least susceptible to aphid. Contrary to the present finding, he reported that genotypes RD-2508 was highly susceptible and it was moderately susceptible in the present findings. Chhillar et al., (1985) reported that out of 30 barley varieties screened, BP-454, EB-921, Wocus and BP-464 were found resistant to aphid those were not included in the present study.

Pandey et al., (1987) reported that out of 197 barley lines screened against aphid, $R$. maidis, 19 were categorized as tolerant to aphid attack, 75 moderately susceptible, 77 susceptible and 26 highly susceptible, but did not corroborate with the present findings due to the difference in varieties included for study. Sharma and Bhatnagar (2003) reported that out of 202 genotypes of barley, ten promising genotypes showed relative resistance to $R$. maidis corroborate the present findings. The significant difference in aphid population among different barley varieties was reported by Sourial and Mitri (2002), Singh and Singh (2009), Akhtar et al., (2011) and Singh and Jat (2011) support the present findings.

\section{Acknowledgement}

The authors are thankful to the Dean, College of Agriculture, Sri Karan Narendra Agriculture University, Jobner- Jaipur for providing necessary facilities and permission to conduct the study.

\section{References}

Akhtar N., Waseem A. Gillani, Ehsan ul Haq, Javed Khan, Irshad Begum, Shaheena Yasmin and Kamran Saeed 2011. Screening for resistance to aphid in barley, Pakistan Journal of Agriculture Research, 24 (1-4): 94.

Anonymous, 2013. Vital Agriculture Statistics. Directorate of Agriculture, Rajasthan, Jaipur.

Bhatia, S.K. and Singh, V.S. 1977. Effect of corn leaf aphid infestation on the yield of barley varieties. Entomon, 2 (1): 6366.

Chhilar, B.S.; Verma, A.N. and Singh, Z. 1985. Screening of some promising barley entries for resistance to the aphid, Rhopalosiphum maidis (Fitch) under artificial infestation conditions. Indian Journal of Entomology, 47 (1): 98-102.

Gomez, K. A. and Gomez, A. A. 1976. Problem data: Statistical Procedures for Agricultural Research (II Ed.). John Wiley and Sons, New York, pp. 272315.

Kumawat, K.C. and Jheeba, S.S. 1999. Varietal screening of barley, Hordeum vulgare L. against aphid, Rhopalosiphum maidis (Fitch). International Journal of Tropical Agriculture, 17 (1/4): 203-207.

Pandey, K.C.; Faruqui, S.A. and Mishra, U.S. 1987. Relative tolerance to aphid, Rhopalosiphum maidis (Fitch) in barley germplasm. Journal of Aphidology, 1 (1\&2): 51-57.

Sharma, H.C. 1990. Bio-ecological investigation and control strategy of barley aphid, Rhopalosiphum maidis (Fitch), with special reference to varietal resistance and estimation of losses to barley crop in Rajasthan. Ph.D. Thesis, submitted to Rajasthan Agricultural University, Bikaner. 
Sharma, H.C. and Bhatnagar, A. 2003. Studies on varietal resistance to barley aphid, Rhopalosiphum maidis (Fitch). Indian Journal of Applied Entomology, 17 (2): 103-108.

Sharma, N.K. 2003. Management of aphid, Rhopalosiphum maidis (Fitch) on barley, Hordeum vulgare Linn. M.Sc. Thesis, Submitted to Rajasthan Agricultural University, Bikaner.

Singh, B. and Singh, S. 2009. Screening and identification of sources of resistance against corn leaf aphid, Rhipalosiphum maidis (Fitch.) in Barley. Indian Journal of Entomology, 71 (3): 255258.

Singh, H. and Jat, B.L. 2011. Bioecology and Management of Aphid, Rhopalosiphum maidis (Fitch) on Barley, Hordeum vulgare Linn. Ph.D. thesis, Submitted to S.K. Rajasthan Agricultural University,
Bikaner (Earstwhile campus Jobner).

Singh, V.S. 1983. Losses due to insect pest in barley. Proceedings of National Seminar on Crop Losses due to Insect Pests, pp. 198.

Singh, B.; Dhindsa, G.S. and Singh H. 2006. Screening of barley (Hordeum vulgare) germplasm against corn leaf aphid, Rhopalosiphum maidis (Fitch.).Crop Improvement, 33(1): 58-61.

Sourial, L.S. and Mitri, S.H. 2002. Laboratory screening barley genotype seedlings for aphid resistance in Egypt. Egyptian Journal of Agricultural Research, 80 (1): 169-179.

Yadav, R.C. and Jain, P.C. 1999. Evaluation of insecticides against barley aphid, Rhopalosiphum maidis (Fitch) on barley (Hordeum vulgare). Annals of Biology, 15 (2): 223-226.

\section{How to cite this article:}

Pawan Kumar Choudhary, Suresh Jakhar and K.C Kumawat. 2017. Reactions of Genotypes of Barley with Aphid (Rhopalosiphum maidis) Population. Int.J.Curr.Microbiol.App.Sci. 6(8): 1148-1154. doi: https://doi.org/10.20546/ijcmas.2017.608.142 